\title{
THE REGIME OF THE MILITARY POSITION AS AN ELEMENT OF THE SYSTEM OF ADMINISTRATIVE MEANS OF EMERGENCY LEGAL REGULATION
}

\section{Kuznichenko S. O.}

\section{INTRODUCTION}

Complications of the military-political situation after the spring of 2014 dramatically influenced the development and functioning of all institutions of public authority without exception. The provisions of legal acts defining the direction of protection of the territorial integrity of the state, the rights and freedoms of citizens, the protection of law and order as components of the national security of Ukraine have undergone significant changes. These circumstances prompted domestic administrative-legal science to intensify scientific research in the field of emergency legal regulation. Among the legal means intended to eliminate dangers and threats, the administrative-legal regime of martial law occupies an important place, and recently, given the existing military-political situation that has developed in Ukraine, it is an object of particular scientific interest. In this direction, researchers help their candidate to defend $\mathrm{PhD}$ theses and doctoral dissertations, publish a large number of monographs and scientific articles, violate the problems of emergency legal regulation in the context of the existence of military threats in theses and reports of numerous scientific conferences.

Only in the last five years, the phenomenon of emergency legal regulators, as a means of ensuring the national security of Ukraine, the rights and freedoms of citizens, ways of their functioning, forms of legal manifestation in the relevant administrative and legal regimes, etc., O.V. Ahapova, S.Ya. Bezkorovainyi, N.M. Biriukova, I.S. Vasylenko, T.V. Vronska, V.O. Holub, V.K. Horovenko, D.O. Yezerskyi, V.V. Yemanov, V.O. Ivakha, N.H. Klymenko, N.V. Kovalenko, V.Ye. Kovryhina, Yu.D. Kuchynskyi, O.V. Levchenko, Yu.O. Leheza, V.V. Malikov, O.V. Makovska, V.V. Maltsev, Yu.V. Nikitin, L.O. Ostapenko, Yu.V. Pavlyshyn, V.H. Pylypchuk, M.L. Pohrebytskyi,
A.I. Rutar,
O.Yu. Salmanova,
A.S. Slavko,
R.M. Skrynkovskyi,
O.M. Sobol,
V.V. Sokurenko, M.P. Stelbytskyi,
V.V. Trotsko, 
V.P. Tiutiunnyk, Yu.O. Fihel, A.I. Kharchuk, O.L. Khytra, L.H. Chystokletov, V.Y. Shevchenko and others have turned their scientific views. The presented spectrum of researchers leaves no doubt that the problem of scientific substantiation of legal regimes belongs to the priority ones. Although the unity in the scientific environment regarding the definition of the legal nature of this phenomenon, its place in the system of law and in the system of legal sciences up to nowadays has not been achieved, and the use of the categories of "legal regime" and "administrative-legal regime" without specifying the characteristic features and its, the structure generates inconsistent scientific conclusions.

Despite the fact that the phenomenon of extraordinary legal regimes was the subject of research by the theorists of law, administrators, specialists in criminal and criminal law, researchers in the field of agrarian and environmental law and other branch legal sciences, however, domestic law science today does not provide detailed answers to a number of questions concerning the sufficiency and adequacy of the grounds for the introduction of the right regime of martial law, the feasibility of the existence of all the restrictions of rights and freedoms on condition of its operation.

The question of the legal regime of the martial law as an extraordinary administrative and legal regulator was raised by us in repeated previous studies, however, the adoption of the Law of Ukraine "On the Legal Status of Military Status" No. 389-VIII of May 12, 2015, the introduction in the separate territories of Ukraine of a martial law by Decree of the President of Ukraine "On the Introduction of the Martial Law in Ukraine" of November 26, 2018, No. 393/2018, makes it necessary to return to this problem in the future, since the new legislation establishes new unique legal relations and for the first time since gaining independence by Ukraine, applies this legal regulator in practice.

The purpose of the study is to find out the place of the legal regime of martial law in the system of domestic emergency administrative legal regulators and study the legal grounds for its introduction.

\section{Location of the Legal Regime in the System of Administrative Means of Extraordinary Legal Regulation}

Under normal circumstances, normal livelihoods of society are supported by historically formed political, legal and economic systems, 
and the established mechanism of governance, which provides for the possibility of using state power measures to ensure stability in society. Such measures allow to maintain the rule of law in the society, provide public safety, protect the rights and freedoms of citizens, etc. However, their application is effective only in a stable socio-political environment, and impossible - when there are extraordinary (extraordinary, extreme, special) circumstances that violate the normal livelihoods of citizens, the functioning of society and the state.

Such circumstances may be of a military nature (aggression from the outside or direct threat of such aggression) or arise under conditions of internal state character (mass riots, attempts to unlawfully change the constitutional order, natural disasters, man-made disasters, etc.). In this regard, researchers of extraordinary legal regulators refer to them, including the regime of martial law, in that part of the law, which reflects the social orientation of political regimes.

Defining it, by the comparative comparison of V.A. Fiodorov, a universal instrument of social engineering, which can serve as an effective means of freedom and security of citizens, as well as a powerful weapon of class domination ${ }^{1,2}$.

As we have noted above, in recent years the situation of Ukraine in many areas of national security has considerably aggravated. This is being influenced both by factors of the internal development of the state and foreign policy circumstances. The past decade has affected the unpredictable changes in the military-political situation in the world, which could not but affect Ukraine. As a result, changes took place in the geopolitical, military, economic and socio-legal plane, which directly affected the security aspects. An analysis of the Strategy of National Security of Ukraine, the Military Doctrine of Ukraine and other similar acts make it possible to distinguish in this part of socio-political relations their external and internal aspects ${ }^{3}$.

1 Федоров В.А. Правовой институт исключительного (военного и чрезвычайного) положения в Российской Федерации : дис. ... канд. юрид. наук : 20.02.03 / Моск. воен. ин-т. погран. службы РФ. Москва, 2003. С. 116.

2 Радченко В.И. Чрезвычайное и военное положение в России (конституционноправовые проблемы) // Вестник Саратовской государственной академии права. 1998. № 3 (14). С. 110.

3 Про рішення Ради національної безпеки і оборони України від 2 вересня 2015 року «Про нову редакцію Воєнної доктрини України» : Указ Президента України від 24 верес. 2015 р. № 555/2015. URL: http://zakon.rada.gov.ua/ laws/show/555/2015 (дата звернення: 02.05.2019). 
In particular, the external ones include: the absence of militarypolitical stability, the emergence of disputed territorial, interethnic, legal and other problems, which, in turn, often grow into military conflicts; destabilization of peaceful initiatives of a number of states on the most important military-political aspects of international security; the presence of an increase in the illicit circulation of nuclear and chemical materials; illegal migration; smuggling of weapons, ammunition, poisonous substances, and so on. The internal aspects include: destabilization of the situation in the financial and scientific and production activities; interethnic, anticonfessional confrontation; acute crisis phenomena in the socio-political sphere; the spread of organized crime into a transnational anti-social system and others.

It follows that legal rules that are designed for law enforcement in normal relationships can be ineffective in extraordinary circumstances. Therefore, the resolution of a crisis situation with ineffective norms can be ensured only by providing public authorities with discretionary powers provided by coercive institutions. The reason for imposing extraordinary legal regimes is the present danger, which threatens values, national interests. Extraordinary legal regimes are caused by two grounds taken in unity: a high degree of danger threatening national interests and invincibility of this danger by other means, except the introduction of extraordinary legal regimes.

It should be noted that the emergence of only one danger is not enough to justify the introduction of an extraordinary legal regime. Such a necessity is recognized as exceptional, caused by an extremely dangerous situation in which the state is compelled to resort to intensive restrictions on the persons who are in its territory as the last resort to eliminate the threat of danger, because other means are absent or inadequate ${ }^{4}$.

The actual cause of emergency legal regimes is a danger that threatens the state and society (not a single person in the general order, but if the danger threatens the president, people's deputy, statesman, then this danger may be recognized as a danger to the state level) ${ }^{5}$. The legal basis takes place throughout the time of existence of danger. At the same

4 Кузніченко С.О. Адміністративно-правовий режим воєнного стану : монографія. Харків : Право, 2014. С. 12-13.

5 Державний класифікатор надзвичайних ситуацій ДК 019-2010: затв. наказом Держстандарту України від 11.10.2010 p. № 457. URL: http://zakon.rada.gov.ua /rada/show/va457609-10 (дата звернення: 04.05.2019). 
time, the termination of the threat of damage indicates a lack of legal basis for extreme legal regimes.

While implementing an emergency regime, it is important to adhere to the principle of adequate response done to prevent excessive interference of state bodies in the constitutional status of the individual. The carrier of the emergency regime is the territory in which the dangerous factors arose. The object of the emergency regime is social relations that affect the degree and nature of the threat of security, the state of public order and life. The choice of a regime depends on the severity of the crisis and the characteristics of its elements: the degree and type of security threat; the nature of the striking factors; magnitude and time aspect of the occurrence of an emergency; multiplicity of consequences, their chain character.

Consequently, the extraordinary legal regimes are quite closely related to the legal status of a person: recent legal phenomena include the rights and responsibilities of the subject. All extreme regimes limit the rights and freedoms of citizens, therefore, such restrictions should, ideally, be fixed only by law. Specific parameters of the legal regimes differ significantly: each regime establishes a certain number of prohibitions and positive obligations. They vary in the depth of change in the constitutional status of citizens, as well as in the territory in which the regime is introduced, and in the course of the regime's operation.

Adoption of the Law of Ukraine "On the Fight against Terrorism" introduced into law a new type of emergency administrative-legal regime - a regime of antiterrorist operation (a special procedure for public administration that can be introduced in the area of the antiterrorist operation) at the time of its implementation, and provide for the subjects of the fight against terrorism, defined by the Law, special (specific) powers necessary for the release of hostages, ensuring the safety and health of people (citizens) who have been in the area held I counterterrorist operation, the normal functioning of state bodies, local authorities, enterprises, institutions, organizations, etc.). The area of the anti-terrorist operation is defined by the leadership of the antiterrorist operation of the area of land or water area, vehicles, buildings, structures, premises and territories or water areas adjacent to them and within which an anti-terrorist operation is carried out ${ }^{6}$.

${ }^{6}$ Про боротьбу з тероризмом : Закон України від 20 бер. 2003 р. № 638-IV. URL: https://zakon.rada.gov.ua/laws/show/638-15 (дата звернення: 04.05.2019). 
The adoption of the Law of Ukraine "On the peculiarities of the state policy of ensuring the state sovereignty of Ukraine in temporarily occupied territories in the Donetsk and Luhansk regions" provided legal preconditions for the political, economic and social integration of certain districts of Donetsk and Luhansk regions to the national legal system and defined the powers of special state institutions in relation to direction, coordination and control over management activities in these territories. However, the rules of this law are represented only by such an extraordinary regulator as the regime of entry / departure of persons, the movement of goods to / from temporarily occupied territories in the Donetsk and Luhansk regions ${ }^{7}$.

The basis of the legal regulation of social relations in special conditions caused by emergency situations of a military nature are the Constitution of Ukraine, laws, regulations of the President and the Government of Ukraine, certain central and local government bodies. The set of normative legal acts that regulate the procedure for the introduction, continuation and abolition of extraordinary administrative and legal regimes, is found in science under the name "system of extraordinary legislation". The main normative legal acts of extraordinary legislation naturally include the laws of Ukraine "On the legal regime of emergency" and "Legal regime of martial law", "On the zone of emergency environmental situation." Some provisions of emergency legislation are also contained in the laws of Ukraine "On the Defense of Ukraine", "On Mobilization Preparation and Mobilization", "On Internal Troops of the Ministry of Internal Affairs of Ukraine", "On the Security Service of Ukraine", "On the State Border of Ukraine", "On Combating with terrorism "and others. Taken together, the mentioned normative legal acts in the legal literature are covered by the terms "extraordinary legislation", "acts of emergency legal regulation," etc.

The study of the world practice of the use of extraordinary legal regulators provides grounds for arguing that extraordinary legislation is a mandatory element of the legal systems of most countries of the world with any form of government. However, depending on the state-legal

${ }^{7}$ Про особливості державної політики із забезпечення державного суверенітету України на тимчасово окупованих територіях у Донецькій та Луганській областях : Закон України від 18 січ. 2018 р. № 2268-VIII. URL: https://zakon.rada.gov.ua/ laws/show/2268-19 (дата звернення: 06.05.2019). 
regime, extraordinary legal acts can occupy a different place in the system of national legislation ${ }^{8}$.

In a democratic state, acts of extraordinary legislation do not replace the effect of the basic laws, but only limit them. They establish such legal rules, the purpose of which is to regulate the basic issues of state, administrative and socio-economic nature in extraordinary circumstances. The main purpose of emergency legislation is to ensure that all legitimate means for a civilized society to eliminate the cause or situation with the least social and material losses, and ultimately ensure the preservation of a democratic regime in an emergency ${ }^{9}$. In the conditions of the introduction of one or another extraordinary administrative-legal regime, restrictions on the rights and freedoms of citizens, as well as the imposition of additional duties on them ${ }^{10}$. Instead, it must be clearly understood that the restriction of certain rights of citizens by the state ensures the observance and protection of their fundamental rights in the event of an emergency.

A characteristic feature of the administrative-legal regimes is the allocation of state authorities with special powers of authority, which are manifested in additional rights and legal capabilities in order to counteract or terminate the negative actions of the subjects or to eliminate the consequences of various nature (natural, man-made, environmental, etc.) to ensure national security, protection of state interests from threats and negative influence of external and internal character ${ }^{11}$.

In countries with authoritarian regimes, almost all legislation on issues of power, political regime, human rights and freedoms, as well as most of the criminal legislation, are of an extraordinary nature. This

8 Кузніченко С.О. Становлення та розвиток інституту надзвичайних адміністративно-правових режимів в України : дис. ... доктора юрид. наук : 12.00.07 / Харківський національний університет внутрішніх справ. Сімферополь, 2010. C. $118-120$.

9 Зиборов О.В. Институт военного положения по российскому праву (историкоправовое исследование) : дисс. ... канд. юрид. наук : 12.00.11 / Московская академия МВД Росии. Москва, 2002. С. 17.

10 Шаповалова, I.О. Нормативно-правове забезпечення службово-бойової діяльності органів внутрішніх справ у надзвичайних ситуаціях техногенного i природного характеру : дис. ... канд. юрид. наук : 21.07.05 / Кримський юрид. ін-т Одеського держ. ун-ту внутр. справ. Сімферополь, 2011. С. 30-47.

${ }^{11}$ Голуб В.О. Становлення та розвиток інституту адміністративно-правового режиму воєнного стану: дис. ... канд. юрид. наук : 12.00.07 / Ін-т законодавства Верховної Ради України. Київ, 2017. С. 25-26. 
practice is typical for transitional regimes, which are formed as a result of the victory of radical opposition forces ${ }^{12}$. Among such regimes are their specific military, established as a result of military coups. Under these regimes, the constitution is suspended or its complete cancellation is announced, dissolution of representative institutions and democratic organizations is carried out, and the full power of the authorities in the center and on the ground belongs to the military command or officials appointed by them ${ }^{13}$.

A prerequisite for effective action of extraordinary legislation is its prior development by the state in peacetime. Only in this case, the emergency legal regime will be applied as efficiently as possible, with the further elaboration of only specific measures in relation to the emergency situation that led to its introduction. If it is not premature to develop legal mechanisms for managing crisis situations (also of a military nature), it is difficult to expect clarity and coherence of actions of authorized entities in the conditions of a real crisis.

In scientific legal literature one can come to the conclusion that the adoption of legislative acts regulating the introduction of an extraordinary administrative-legal regime in peaceful times is inappropriate, since it can be perceived as a preparation for the collapse of democratic state-legal institutes or war and will cause anxiety in other states $^{14,15}$.

Based on the study of the historical experience of different states regarding the application of emergency law can identify a number of inherent features that characterize it as a legal instrument, designed to serve the interests of the nation and not to threaten its spiritual values:

1) extraordinary legislation is based on the constitution and generally accepted principles and norms of international law, which guarantee the soundness and legitimacy of the use of emergency measures;

12 Байтин М.И. О современном нормативном понимании права. 1999. Журнал Российского права. № 1. С. 101.

13 Дубко Ю.В. Діяльність поліції тоталітарних, авторитарних та демократичних країн у надзвичайних умовах. 2009. Право і суспільство. № 2. С. 41-44.

14 Федоров В.А. Правовой институт исключительного (военного и чрезвычайного) положения в Российской Федерации : дис. ... канд. юрид. наук : 20.02.03 / Моск. воен. ин-т. погран. службы РФ. Москва, 2003. С. 60-71.

15 Пчелинцев, С.В. Правовое регулирование военного положения в Российской Федерации : дис. ... канд. юрид. наук : 20.02.03 / Военный Ун-т. Москва, 1998. C. $70-120$. 
2) the very existence of emergency legislation provides for the possibility of emerging in the life of society and the state of large-scale extreme situations of war, social, technological and natural character, which create a real and inevitable threat to the security of man, society and the state as a whole;

3) the objectives and tasks of extraordinary legislation are to prevent and eliminate the abovementioned social and natural disasters, to ensure the safety of citizens, to protect their rights and freedoms, the foundations of the constitutional system, the interests of society and the state, the restoration of the rule of law and order;

4) the application of the rules of extraordinary legislation leads to the redistribution of mutual rights and obligations of the citizen and the state - the extension of the powers of state authorities due to some restriction of the rights and freedoms of citizens ${ }^{16}$;

5) the extraordinary situation that is the basis for the application of extraordinary legislation, provides for the creation of special authorities and management with specific tasks and functions, which concentrate significant powers to eliminate the emerging emergency ${ }^{17}$;

6) emergency legislation is intended to legally establish the application of "emergency measures" within the framework of the imposed emergency administrative-legal regime of the exercise of state power (for example, the introduction of a curfew, the prohibition of strikes, mass events, etc.);

7) the existence in emergency legislation of only imperative norms that do not allow any deviation from its content, since any derogation from the provisions of emergency laws can lead to gross violations of law and, consequently, to the restriction of the rights, freedoms and legitimate interests of citizens who under conditions of emergency legislation become the most vulnerable ${ }^{18}$.

16 Кузніченко С.О. Становлення та розвиток інституту надзвичайних адміністративно-правових режимів в України : дис. ... доктора юрид. наук : 12.00.07 / Харківський національний університет внутрішніх справ. Сімферополь, 2010. С. 56, 69-70, 90-91.

Кузніченко С.О. Адміністративно-правовий режим воєнного стану: монографія. Харків : Право, 2014. 232 с.

Шаповалова I.O. Нормативно-правове забезпечення службово-бойової діяльності органів внутрішніх справ у надзвичайних ситуаціях техногенного i природного характеру : дис. ... канд. юрид. наук : 21.07 .05 / Кримський юрид. ін-т Одеського держ. ун-ту внутр. справ. Сімферополь, 2011. С. 19-21. 


\section{Legal Regulation of the Mod of War}

According to Art. 1 of the Law of Ukraine "On the Legal Status of Military Status", a state of war is a special legal regime introduced in Ukraine or in its separate areas in the event of armed aggression or threat of attack, the danger of Ukraine's state independence, its territorial integrity and provides for the provision of appropriate state authorities , military command, military administrations and local self-government powers necessary to prevent the threat, rebuff armed aggression and ensure national security, eliminate threats and the danger of the state independence of Ukraine, its territorial integrity, as well as the temporary, threatened, restriction of the constitutional rights and freedoms of man and citizen and the rights and legitimate interests of legal entities, indicating the validity of these restrictions ${ }^{19}$. A similar, but literally not identical definition of this concept contains and paragraph 12 of Art. 1 of the Law of Ukraine "On the Defense of Ukraine"20.

The concept of a "military state" is etymologically combined with war, a kind of socio-political and legal category, which encyclopedias are defined as "a complex socio-political phenomenon associated with the resolution of contradictions between states, peoples, national and social groups with the transition to application means of armed struggle that takes place in the form of fighting between their armed forces"21.

From a legal point of view, the war has certain characteristics: a) a formal act of the announcement, as required by the IV Hague Convention of 1907 ; b) the dissolution of diplomatic relations between the belligerent states, which is the result of the declaration of war; c) annulment of bilateral agreements, especially political ones; d) a special legal regime, which characterizes partial restrictions on human rights, etc., begins.

The use of these particular features of the war against the ongoing armed conflicts brings us beyond the concept of "war" as military adversaries carry out military actions by combining militarily, quasimilitarily, diplomatic, informational, economic, and other means to achieve strategic political goals.

19 Про правовий режим воєнного стану : Закон України від 12 трав. 2015 р. № 389-VIII. URL: https://zakon.rada.gov.ua/laws/show/389-19 (дата звернення 02.05.2019).

${ }^{20}$ Про оборону України : Закон України від 6 груд. 1991 р. № 1932-XII. URL: https://zakon.rada.gov.ua/laws/show/1932-12 (дата звернення 03.05.2019).

${ }^{21}$ War. Encyclopedia Britannica. URL: https://www.britannica.com/topic/war (дата звернення: 06.05.2019). 
Thus, the concept of war should be considered within the framework of an "armed conflict" (armed conflict), which involves two compulsory components - the presence of organized armed contingents and engagement in combat operations of a certain intensity ${ }^{22}$.

Many legal acts dealing with issues of national security also use the term "special period"23,24,25,26,27. As to the term "wartime", it is appropriate to emphasize that it means the time of the administrativelegal regime of the military state, and is not a separate type of extraordinary administrative-legal regime, and has fallen into the legislation of Ukraine in the process of implementation of international normative legal acts ratified by the state ${ }^{28}$.

Particular attention deserves the notion of "state of war", which is enshrined in the legislation of Ukraine, national laws of other states and international law. Encyclopedic literature defines the notion of "state of war" as "... the state of armed confrontation between states (blocs of states). Begining from the moment the official statement (notice or note) of the competent authority of the country regarding the commencement of hostilities against another state and the cessation of peaceful relations between them" 29 .

${ }^{22}$ Final Report on the Meaning of Armed Conflict in International Law. The Hague Conference (2010). Use of Force. URL: http://www.ila-hq.org/download.cfm/ docid/2176DC63-D268-4133-8989A664754F9F87 (дата звернення 03.05.2019).

${ }^{23}$ Про оборону України : Закон України від 6 груд. 1991 р. № 1932-XII. URL: https://zakon.rada.gov.ua/laws/show/1932-12 (дата звернення 03.05.2019).

${ }^{24}$ Про затвердження Положення про організацію готівкового обігу і ведення емісійно-касових операцій у банківській системі в особливий період : Постанова Правління Національного банку України від 05 трав. 2018 р. № 51. URL: https://zakon.rada.gov.ua/laws/show/v0051500-18 (дата звернення: 03.05.2019).

25 Про положення про проходження військової служби відповідними категоріями військовослужбовців : Указ Президента України від 07 жовт. 2001 р. № 1053/2001. URL: http://zakon.rada.gov.ua/laws/show/1053/2001 (дата звернення 03.05.2019).

${ }^{26}$ Про функціонування єдиної транспортної системи України в особливий період : Закон України від 20 жовт. 1998 p. № 194-IV. URL: http://zakon.rada.gov.ua/laws/show/194-14 (дата звернення 03.05.2019).

${ }^{27}$ Про мобілізаційну підготовку та мобілізацію : Закон України від 21 жовт. 1993 p. № 3543-XII. URL: https://zakon.rada.gov.ua/laws/main/3543-12 (дата звернення 02.05.2019).

${ }^{28}$ Конвенція про захист цивільного населення під час війни, 1949 р.: міжнародний документ: Міжнародний документ ООН від 12 серп. 1949 р. № 995_154. URL: https://zakon.rada.gov.ua/laws/show/995 154 (дата звернення 03.05.2019).

${ }^{29}$ Юридична енциклопедія в 6 т. / голова редкол. Ю.С. Шемшученко. Київ: Укр. енциклоп., 1998. Т. 1: А-Г. С. 613. 
Mobilization as a type of activity also has its legal regime. However, in our opinion, talking about mobilization as a separate extraordinary administrative-legal regime is incorrect. This also applies to evacuation as a set of measures for the organized removal (removal) of population from areas (places), zones of possible influence of the negative factor and its placement in safe areas (places) in case of a direct threat to life and causing harm to people's health ${ }^{30}$.

Having systematized all approaches to defining the concept of "military state", as well as the main features of this administrative-legal regime. A detailed analysis of the development of legislation regulating the legal regime of martial law has made it possible to distinguish the following main features of this regime: state powers for the organization of defense, security and public order can be transferred to military command; the bodies of the military command are endowed with the powers of emergency, as well as the right to publish mandatory statutory acts (see paragraph 32, paragraph 4, of the Regulation on the Ministry of Defense of Ukraine, sub-items 10, 61 and 81, paragraph 4 of the Regulation on the General Staff of the Armed Forces of Ukraine, approved by the Decree of the President of Ukraine dated 06.04.2011 №406 / 2011 ${ }^{31}$; on state bodies, enterprises, institutions, organizations (regardless of the form of ownership) and citizens are assigned additional defense responsibilities ${ }^{32}$; legal liability for certain offenses is increasing (see Article 5, Article 35 of the Code of Ukraine on Administrative Offenses ${ }^{33}$, p. 11 part 1, Article 67, Part 3 of Article 402, Part 2, Article 403, part. 3 articles 404, part 4, article 407, etc. The Criminal Code of Ukraine ${ }^{34}$.

${ }^{30}$ Про затвердження Порядку проведення евакуації у разі загрози виникнення або виникнення надзвичайних ситуацій : Постанова Кабінету міністрів України від 30 жовт. 2013 р. № 814. URL: https://zakon.rada.gov.ua/laws/show/841-2013-п (дата звернення 02.05.2019).

31 Про Положення про Міністерство оборони України та Положення про Генеральний штаб Збройних Сил України : Указ Президента України від 06 квітн. 2011 p. № 406/2011. URL: http://zakon.rada.gov.ua/laws/show/406/2011 (дата звернення 03.05.2019).

32 Про затвердження Положення про військово-транспортний обов'язок : Постанова Кабінету Міністрів України від 28 лист. 2000 р. № 1921. URL: https://zakon.rada.gov.ua/laws/show/1921-2000-п (дата звернення 05.05.2019).

${ }^{33}$ Кодекс України про адміністративні правопорушення : Закон України від 07 груд. 1984 р. № № 8073-X. URL: https://zakon.rada.gov.ua/go/80731-10 (дата звернення 30.04.2019).

${ }^{34}$ Кримінальний кодекс України : Закон України від 05 квіт. 2001 р. № № 2341III. URL: https://zakon.rada.gov.ua/laws/show/2341-14 (дата звернення 02.05.2019). 
From the specified norms of tort law, it is seen that crimes committed in the conditions of a martial law, punishments for which, usually adequate to their social danger, are repressive. That is, as D.V. Bondarenko, the law of wartime involves not only increasing the criminal liability for crimes that constitute an increased public danger, but also a special procedure for the implementation of criminal-procedural relations, distinguished by simplified and accelerated procedures ${ }^{35}$.

In the science of state law in Soviet times, the characteristic features of the military state were the presence of increased responsibility for the laws of war, advocating for non-compliance with the administrative acts (orders) of the military authorities, as well as the application to citizens of a number of restrictions on civil rights and the imposition of additional duties on them ${ }^{36}$.

Thus, the legal regime of martial law as an extraordinary legal regulator covers a number of closely related elements of a legal nature.

It should be noted that the introduction of martial law is always accompanied by the introduction of a number of emergency measures that cannot be applied under normal conditions. In administrative-legal science, the idea like that measures are manifested in forms: the creation of special authorities; publication of special legal acts; the use of "reinforced measures" to protect public order and ensure public safety; if necessary - restricting the rights and freedoms of citizens, as well as expanding their responsibilities ${ }^{37}$.

By systematizing approaches to the definition of the "administrative-legal regime of martial law", V.O. Holub distinguishes its main features, namely: the power to organize defense, security and public order can be transferred to the military command; the military commanders are endowed with powers of a special nature, as well as the right to publish mandatory statutory acts; state agencies, citizens, enterprises, institutions and organizations may rely on additional defense liabilities; there is a legal possibility of a temporary, threatened threat to

35 Бондаренко Д.В. Юридическая ответственность в условиях военного положения: на опыте Великой Отечественной войны 1941-1945 гг. : дисс. ... канд. Юрид. Наук : 12.00.01 / Российская академия правосудия. Москва, 2005. С. 99-114.

36 Румянцев О.Г. Додонов В.Н. Юридический энциклопедический словарь. Москва : Инфра-М, 1996. С. 43.

37 Зиборов О.В. Институт военного положения по российскому праву (историко-правовое исследование) : дисс. ... канд. юрид. наук : 12.00.11 / Московская академия МВД Росии. Москва, 2002. С. 30. 
national security, restriction of constitutional rights and freedoms of man and citizen and the rights and legitimate interests of legal persons ${ }^{38}$.

Political and legal features of the legal regime of a military or extraordinary state, as extraordinary legal regulators, are manifested in the following: 1) the transition of the supreme power in the state to the military administration, accompanied by either the dissolution of representative bodies, or the actual cessation of their activities; 2) significant expansion of the powers of the administrative apparatus and law enforcement agencies; 3 ) the cancellation or suspension of the basic constitutional rights of citizens or their restriction; 4) strengthening of criminal and administrative liability - increase of sanctions for one or another offense (also for violation of the extraordinary administrativelegal regime), the introduction of the death penalty or the extension of its use, the introduction of administrative link and deportation, the abolition of restrictions on the use of armed forces and police physical coercion measures; 5) extension of the range of compulsory state duties of the population, introduction of labor and transport, duties on civil defense, etc.; 6) the abolition or restriction of freedom of residence, movement, choice of profession; establishment of prohibited zones, areas of enhanced police control; the introduction of a permit system for the choice of place of residence and movement of the country; lock-in at work, forced labor movement, etc.; 7) significant restrictions on the institutions of freedom of property and treaties; the introduction of a permit system for the opening or reorganization of an enterprise, the use of raw materials and manpower; establishment of sales markets, systems of compulsory state orders; state-building of enterprises, carrying out of forced confiscations and audits; 8) standardization of civil circulation, establishment of prices for consumer goods, rent and other services; a decrease in wage and social security levels ${ }^{39}$.

Based on the provisions of the Law of Ukraine "On the Legal Status of Military Status," the wording of the legal basis for the introduction of a military state should be based on the following legal categories: "armed aggression", "threat of attack", "danger of state independence",

38 Голуб В.О. Становлення та розвиток інституту адміністративно-правового режиму воєнного стану : дис. ... канд. юрид. наук : 12.00.07 / Ін-т законодавства Верховної Ради України. Київ, 2017. С. 33.

39 Чрезвычайное законодательство ФРГ / под ред. В.М. Чхиквадзе. Москва : Юрид. лит., 1970. С. 19-21. 
"danger of territorial integrity" despite the fact that the Law itself does not provide definitions of these categories. The legal category "armed aggression" is defined by Article 1 of the Law of Ukraine "On Defense", which is:

$\checkmark$ application by another state or group of armed forces against Ukraine. An armed aggression against Ukraine is any of the following:

$\checkmark$ invasion or attack of the armed forces of another state or group of states on the territory of Ukraine, as well as the occupation or annexation of part of the territory of Ukraine;

$\checkmark$ blockade of ports, coast or airspace, violation of Ukraine's communications by armed forces of another state or group of states;

$\checkmark$ an attack of the armed forces of another state or group of states on military land, naval or air forces or civilian sea or air fleets of Ukraine;

$\checkmark$ sending by or on behalf of another state armed groups of regular or irregular forces committing acts of armed force against Ukraine which are so serious that they are equally marked in paragraphs 5 to 7 of this article, including significant participation third state in such actions;

$\checkmark$ the action of another State (s) that allows its territory which it has provided to a third State to be used by that third State (s) to commit the acts specified in paragraphs five to eighth of this article;

$\checkmark$ application of units of the armed forces of another state or group of states that are in the territory of Ukraine in accordance with international treaties concluded with Ukraine against a third state or group of states; another violation of the conditions stipulated by such agreements or continuation of stay of these units on the territory of Ukraine after termination of action specified contracts ${ }^{40}$.

The category "threat of attack" is not defined by any normative legal act. However, the Military Doctrine of Ukraine contains the wording "the threat of using military force" - the intentions or actions of one of the parties of military-political relations, which indicate willingness to use military force against the other party in order to achieve their own goals. The threat of the use of military force arises when the state takes measures for direct preparation for war $^{41}$.Such

${ }^{40}$ Про оборону України : Закон України від 6 груд. 1991 р. № 1932-XII. URL: https://zakon.rada.gov.ua/laws/show/1932-12 (дата звернення 03.05.2019).

41 Левченко О.В. Уточнення понятійного апарату з питань оцінювання рівня воєнної загрози національній безпеці України. 2014. Наука і оборона. № 2. С. 18. 
qualification as "the danger of the state independence of Ukraine" should be interpreted on the basis of its constituent "danger" - it is an objective phenomenon of the material world, processes, objects that are capable under certain conditions to cause damage to the subject as immediately, and in the future, that is, to cause undesirable consequences ${ }^{42}$ and "state independence" - the supremacy of state power within the country, independence in international relations ${ }^{43}$.

The dangers of territorial integrity include the facts of the existence in the state of armed conflicts of a non-international nature - so-called internal armed conflicts. Article 1 of the Additional Protocol to the Geneva Conventions of August 12,1949, refers to all armed conflicts that are not subject to any armed conflict occurring on the territory of any State between its armed forces or other organized armed groups which, under responsible command, exercise such control over part of its territory that allows them to carry out continuous and coordinated hostilities and apply the provisions of Protocol II of the Geneva Conventions ${ }^{44}$.

The Law of Ukraine "On the Fundamentals of National Security of Ukraine" defines sovereignty, territorial integrity and inviolability of objects of national security, and attacks on the sovereignty of Ukraine and its territorial integrity, territorial claims by other states - threats to national security - existing and potentially possible phenomena and factors that pose a threat to Ukraine's vital national interests. "In addition, the said Law defines ${ }^{45}$.

The legal basis for the defense of the country as a system of political, economic, social, military, scientific, scientific, technical, informational, legal, organizational, other measures of the state regarding preparation for armed defense and its protection in the event of armed aggression or armed conflict is the Constitution of

42 Березюк О.В., Лемешев М.С. Безпека життєдіяльності: навч. посібник. Вінниця: Вінниц. нац. техн. ун-т., 2011. С. 28.

43 Левин, Д.Б. Основные проблемы современного международного права / Под ред.. Гайдукова Д.А. Москва : Госюриздат, 1958. С. 200.

${ }_{44}$ Додатковий протокол до Женевських конвенцій від 12.08.1949, що стосується захисту жертв збройних конфліктів не міжнародного характеру : Протокол II від 08 черв. 1977 p. URL: http://zaкon1.rada.gov.ua/laws/show/995_200 (дата звернення 05.05.2019).

45 Про основи національної безпеки України : Закон України від 21 черв. 2018 р. № 2469 - VIII. URL: http://zakon.rada.gov.ua/laws/show/-2469-19 (дата звернення 02.05.2019). 
Ukraine $^{46}$, the Law of Ukraine "On the Defense of Ukraine"47, other legislative acts of Ukraine and relevant international agreements, the consent of which is binding on the Verkhovna Rada of Ukraine.

Thus, the Law of Ukraine "On Defense of Ukraine" defines the principles of its defense, as well as the powers of state authorities, the main functions and tasks of the bodies of military management, local state administrations, local self-government bodies, the responsibilities of enterprises, institutions, organizations, officials, law and responsibilities of Ukrainian citizens in the field of defense $e^{48}$. In particular, it was established that the defense of the country is based on the willingness and ability of state authorities, all parts of the military organization of Ukraine, local self-government, a unified civil defense system, the national economy to transfer, if necessary, from peaceful to military status and repression of armed aggression, liquidation armed conflict, as well as readiness of the population and the territory of the state for defense.

Specificity of legal relations related to the implementation of legal norms governing the legal regime of martial law, determines the totality of regulatory legal means, which in a martial law acquire a completely new meaning. In particular, the unique, other extraordinary legal regimes, include the introduction of an institution of military administrations that may be formed in the territories in which the state of war was introduced and the provision of the right to take measures of the legal regime of the military state to the military command, to which the law refers the General Staff The Armed Forces of Ukraine, the Joint Operational Headquarters of the Armed Forces of Ukraine, the command of the Armed Forces of Ukraine, the command of the Special Forces Special Forces of the Armed Forces of Ukraine, the command of Airborne Assault the Army of the Armed Forces of Ukraine, the command of the operational commands, the command of the unions and military units of the Armed Forces of Ukraine ${ }^{49}$.

46 Конституція України : Закон України від 28 черв. 1996 р. № 254к/96-ВР. URL: http://zakon.rada.gov.ua/laws/show/254к/96-BP (дата звернення: 03.05.2019).

47 Про оборону України: Закон України від 6 груд. 1991 р. № 1932-XII. URL: https://zakon.rada.gov.ua/laws/show/1932-12 (дата звернення 03.05.2019).

${ }^{48}$ Ibidem.

49 Про правовий режим воєнного стану : Закон України від 12 трав. 2015 р. № 389-VIII. URL: https://zakon.rada.gov.ua/laws/show/389-19 (дата звернення 03.05.2019). 


\section{CONCLUSIONS}

Thus, summing up, we note that the legal regime of martial law must be a system of interconnected and complementary legal norms regulating: the grounds for its introduction; the activities of the entities authorized to enter, abolish and implement appropriate measures; the procedure for its introduction; the operation of the legal regime of the military state in time, space and in the circle of persons; a mechanism for limiting the rights and freedoms of citizens, as well as responsibilities that are relied on by legal entities and individuals. In our view, only in the case of such detailed regulation, the institution of martial law will have a constitutional character and signs of legitimacy.

The legal regulation of the military state regime is characterized by the use of a number of evaluative and abstract concepts such as "military threat", "threat of aggression", and others. Such legal formulas are inherent in the regulation of a very wide range of social relations. Legal application under the legal regime of a martial law is carried out with a wide range of freedom of discretion, which may lead to a lack of uniformity in the interpretation and application of extraordinary legal norms.

The presence of gaps in the law on a military state is due to the impossibility of forecasting all possible situations in the field of social relations that arise in the context of martial law. This necessitates the use of law enforcement in the provision of a military state to be guided not only by the legal rules deriving from the laws and acts of international law, but also the basic principles of law.

At the legislative level, it is necessary to balance the proportionality of the restriction of rights and freedoms by determining the amount of forces and means necessary to reject aggression or attack, depending on the level and extent of the military conflict.

\section{SUMMARY}

In the article the author investigates the legal regime of martial law in the system of domestic emergency administrative legal regulators and the legal grounds for its introduction.

On the basis of studying the historical experience of different states regarding the application of extraordinary legislation, defines a number of inherent features that characterize it as a legal instrument designed to serve the interests of the nation and not to threaten its spiritual values, 
and also distinguishes the features of the war from a legal point of view. Emphasizes the political and legal features of the legal regime of a military or extraordinary state, as extraordinary legal regulators. Stresses that the legal regulation of the military state regime is characterized by the use of a number of evaluative and abstract concepts, in particular such as "military threat" and "threat of aggression".

On the basis of the analysis of normative legal acts, the author states that the existence of gaps in the law on the military state is due to the impossibility of forecasting all possible situations in the sphere of social relations that arise in the conditions of a martial law. This necessitates the use of law enforcement in the provision of a military state to be guided not only by the legal rules deriving from the laws and acts of international law, but also the basic principles of law.

It is considered necessary at the legislative level to balance the proportionality of the restriction of rights and freedoms by determining the amount of forces and means necessary to reject aggression or attack, depending on the level and extent of the military conflict.

\section{REFERENCES}

1. Final Report on the Meaning of Armed Conflict in International Law. The Hague Conference (2010). Use of Force. URL: http://www.ila-hq.org/download.cfm/docid/2176DC63-D268-4133-89 89A664754F9F87 (дата звернення 03.05.2019).

2. War. Encyclopedia Britannica. URL: https://www.britannica.com/ topic/war (дата звернення: 06.05.2019).

3. Байтин М.И. О современном нормативном понимании права. Журнал Российского права. 1999. № 1. С. 98-107.

4. Березюк О.В., Лемешев М.С. Безпека життєдіяльності: навч. посібник. Вінниця: Вінниц. нац. техн. ун-т., 2011. 203 с.

5. Бондаренко Д.В. Юридическая ответственность в условиях военного положения: на опыте Великой Отечественной войны 1941-1945 гг. : дисс. ... канд. юрид. наук : 12.00.01 / Российская академия правосудия. Москва, 2005. 223 с.

6. Голуб В.О. Становлення та розвиток інституту адміністративно-правового режиму воєнного стану : дис. ... канд. юрид. наук : 12.00.07 / Ін-т законодавства Верховної Ради України. Київ, 2017. $248 \mathrm{c}$. 
7. Державний класифікатор надзвичайних ситуацій ДК 0192010: затв. наказом Держстандарту України від 11 жовт. 2010 р. № 457. URL: http://zakon.rada.gov.ua/rada/show/va457609-10 (дата звернення: 04.05.2019).

8. Додатковий протокол до Женевських конвенцій від 12.08.1949, що стосується захисту жертв збройних конфліктів не міжнародного характеру : Протокол II від 08 черв. 1977 p. URL: http://zaкon1.rada.gov.ua/laws/show/995_200 (дата звернення 05.05.2019).

9. Дубко Ю.В. Діяльність поліції тоталітарних, авторитарних та демократичних країн у надзвичайних умовах. Право $i$ суспільство. 2009. № 2. С. 40-45.

10. Зиборов О.В. Институт военного положения по российскому праву (историко-правовое исследование) : дисс. ... канд. юрид. наук : 12.00.11 / Московская академия МВД Росии. Москва, 2002. 222 с.

11. Кодекс України про адміністративні правопорушення : Закон України від 07 груд. 1984 p. № 8073-X. URL: https://zakon.rada.gov.ua/go/80731-10 (дата звернення 06.05.2019).

12. Конвенція про захист цивільного населення під час війни, 1949 р.: Міжнародний документ ООН від 12 серп. 1949 p. № 995_154. URL: https://zakon.rada.gov.ua/laws/show/995_154 (дата звернення 03.05.2019).

13. Конституція України : Закон України від 28 черв. 1996 р. № 254к/96-BP. URL: http://zakon.rada.gov.ua/laws/show/254к/96-BP (дата звернення: 03.05.2019).

14. Кримінальний кодекс України : Закон України від 05 квіт. 2001 p. № № 2341-III. URL: https://zakon.rada.gov.ua/laws/show/234114 (дата звернення 02.05.2019).

15. Кузніченко С.О. Адміністративно-правовий режим воєнного стану : монографія. Харків: Право, 2014. 232 с.

16. Кузніченко С.О. Становлення та розвиток інституту надзвичайних адміністративно-правових режимів в України: дис.... доктора юрид. наук: 12.00 .07 / Харківський національний університет внутрішніх справ. Сімферополь, 2010. 463 с.

17. Левин Д.Б. Основные проблемы современного международного права / Под ред. Гайдукова Д.А. Москва: Госюриздат, 1958. $275 \mathrm{c}$. 
18. Левченко О.В. Уточнення понятійного апарату 3 питань оцінювання рівня воєнної загрози національній безпеці України. Наука і оборона. 2014. № 2. С. 16-19.

19. Міжнародне публічне право : підручник / В.М. Репецький та ін. ; за ред. проф. В.М. Репецького. Київ: Знання, 2012. 437 с.

20. Про боротьбу з тероризмом : Закон України від 20 бер. 2003 p. № 638-IV. URL: https://zakon.rada.gov.ua/laws/show/638-15 (дата звернення: 04.05.2019).

21. Про затвердження Положення про військово-транспортний обов'язок : Постанова Кабінету Міністрів України від 28 лист. 2000 p. № 1921. URL: https://zakon.rada.gov.ua/laws/show/1921-2000п (дата звернення 05.05.2019).

22. Про затвердження Положення про організацію готівкового обігу і ведення емісійно-касових операцій у банківській системі в особливий період : Постанова Правління Національного банку України від 05 трав. 2018 р. № 51. URL: https://zakon.rada.gov.ua/ laws/show/v0051500-18 (дата звернення: 03.05.2019).

23. Про затвердження Порядку проведення евакуації у разі загрози виникнення або виникнення надзвичайних ситуацій : Постанова Кабінету міністрів України від 30 жовт. 2013 р. № 814. URL: https://zakon.rada.gov.ua/laws/show/841-2013-п (дата звернення 02.05.2019).

24.Про мобілізаційну підготовку та мобілізацію : Закон України від 21 жовт. 1993 р. № 3543-XII. URL: https://zakon.rada.gov.ua/laws/main/3543-12 (дата звернення 02.05.2019).

25. Про оборону України : Закон України від 6 груд. 1991 р. № 1932-XII. URL: https://zakon.rada.gov.ua/laws/show/1932-12 (дата звернення 03.05.2019).

26. Про основи національної безпеки України : Закон України від 21 черв. 2018 р. № 2469 - VIII. URL: http://zakon.rada.gov.ua/ laws/show/-2469-19 (дата звернення 02.05.2019).

27. Про особливості державної політики із забезпечення державного суверенітету України на тимчасово окупованих територіях у Донецькій та Луганській областях : Закон України від 18 січ. 2018 p. № 2268-VIII. URL: https://zakon.rada.gov.ua/laws/ show/2268-19 (дата звернення: 06.05.2019). 
28. Про Положення про Міністерство оборони України та Положення про Генеральний штаб Збройних Сил України : Указ Президента України від 06 квітн. 2011 р. № 406/2011. URL: http://zakon.rada.gov.ua/laws/show/406/2011 (дата звернення 03.05.2019).

29. Про положення про проходження військової служби відповідними категоріями військовослужбовців : Указ Президента України від 07 жовт. 2001 p. № 1053/2001. URL: http://zakon.rada.gov.ua/laws/show/1053/2001 (дата звернення 03.05.2019).

30. Про правовий режим воєнного стану : Закон України від 12 трав. 2015 р. № 389-VIII. URL: https://zakon.rada.gov.ua/ laws/show/389-19 (дата звернення 02.05.2019).

31. Про правовий режим воєнного стану : Закон України від 12 трав. 2015 р. № 389-VIII. URL: https://zakon.rada.gov.ua/laws/ show/389-19 (дата звернення 03.05.2019).

32. Про рішення Ради національної безпеки і оборони України від 2 вересня 2015 року «Про нову редакцію Воєнної доктрини України» : Указ Президента України від 24 верес. 2015 р. № 555/2015. URL: http://zakon.rada.gov.ua/laws/show/555/2015 (дата звернення: 02.05.2019).

33. Про функціонування єдиної транспортної системи України в особливий період : Закон України від 20 жовт. 1998 р. № 194-IV. URL: http://zakon.rada.gov.ua/laws/show/194-14 (дата звернення 03.05.2019).

34. Пчелинцев С.В. Правовое регулирование военного положения в Российской Федерации : дис. ... канд. юрид. наук : 20.02.03 / Военный Ун-т. Москва, 1998. 234 с.

35. Радченко В.И. Чрезвычайное и военное положение в России (конституционно-правовые проблемы). Вестник Саратовской государственной академии права. 1998. № 3(14). С.109-119.

36. Румянцев О.Г. Додонов В.Н. Юридический энциклопедический словарь. Москва : Инфра-М, 1996. 376 с.

37. Федоров В.А. Правовой институт исключительного (военного и чрезвычайного) положения в Российской Федерации : дис. ... канд. юрид. наук : 20.02.03 / Моск. воен. ин-т. погран. службы РФ. Москва, 2003. 231 с. 
38. Чрезвычайное законодательство ФРГ / под ред. В.М. Чхиквадзе. Москва : Юрид. лит., 1970. 210 с.

39. Шаповалова I.O. Нормативно-правове забезпечення службово-бойової діяльності органів внутрішніх справ у надзвичайних ситуаціях техногенного і природного характеру: дис.... канд. юрид. наук : 21.07.05 / Кримський юрид. ін-т Одеського держ. ун-ту внутр. справ. Сімферополь, 2011. 260 с.

40. Юридична енциклопедія в 6 т. / голова редкол. Ю.С. Шемшученко. Київ: Укр. енциклоп., 1998. Т. 1: А-Г. 672 с.

Information about the author: Kuznichenko S. O. Doctor of Laws, Professor, Vice-rector, Odessa State University Ministry of Internal Affairs 1, Uspenskaya str., Odessa, Ukraine 